Portland State University

PDXScholar

\title{
Pilot Study on the Impact of Green Roofs on Ozone Levels Near Building Ventilation Air Supply
}

\author{
Pradeep Ramasubramanian \\ Portland State University \\ Olyssa Starry \\ Portland State University, ostarry@pdx.edu \\ Todd Rosenstiel \\ Portland State University, rosensti@pdx.edu \\ Elliott T. Gall \\ Portland State University, gall@pdx.edu
}

Follow this and additional works at: https://pdxscholar.library.pdx.edu/honors_fac

\section{Let us know how access to this document benefits you.}

\section{Citation Details}

Ramasubramanian, P., Starry, O., Rosenstiel, T., \& Gall, E. T. (2019). Pilot study on the impact of green roofs on ozone levels near building ventilation air supply. Building \& Environment, 151, 43-53. https://doi.org/ 10.1016/j.buildenv.2019.01.023

This Post-Print is brought to you for free and open access. It has been accepted for inclusion in University Honors College Faculty Publication and Presentations by an authorized administrator of PDXScholar. Please contact us if we can make this document more accessible: pdxscholar@pdx.edu. 
Pilot Study on the Impact of Green Roofs on Ozone Levels Near B uilding Ventilation Air Supply

Pradeep Ramasubramanian

Department of Mechanical and Materials Engineering, Portland State University, Portland, OR, USA

Olyssa Starry

Honors College, Portland State University, Portland, OR, USA

Todd Rosenstiel

Department of Biology, Portland State University, Portland, OR, USA

Elliott T. Gall*

Department of Mechanical and Materials Engineering, Portland State University, Portland, OR, USA

*Corresponding Email and Phone: gall@pdx.edu, 503-725-2878

*Corresponding Fax: 503-725-8255 


\section{ABSTRACT}

Outdoor air is often introduced into commercial buildings from ventilation intakes sited on rooftops where vegetation (a green roof) is increasingly present. Little is known about the impact of green roofs on the quality of building outdoor ventilation air supply. In this study, we investigated the potential for green roofs to impact ozone $\left(\mathrm{O}_{3}\right)$ levels in ventilation air by parameterizing $\mathrm{O}_{3}$ dry deposition to vegetation and substrate typical of extensive green roofs in field and laboratory studies. Values obtained constrain a 2-D advection-diffusion model of $\mathrm{O}_{3}$ transport and reaction at the rooftop scale. The $10^{\text {th }}, 50^{\text {th }}$, and $90^{\text {th }}$ percentiles for $\mathrm{O}_{3}$ surface resistances measured using flux-gradient methods in field studies were $46 \mathrm{~s} / \mathrm{m}$, $155 \mathrm{~s} / \mathrm{m}$, and $1700 \mathrm{~s} / \mathrm{m}$. Surface resistances measured in laboratory chambers for substrate and green roof samples ranged from $360 \mathrm{~s} / \mathrm{m}$ to $435 \mathrm{~s} / \mathrm{m}$, in the $60^{\text {th }}-70^{\text {th }}$ percentile of field measurements. The modelled impact of a green roof on $\mathrm{O}_{3}$ levels in building outdoor ventilation air intake was a reduction ranging from 0.25 to $1.8 \mu \mathrm{g} / \mathrm{m}^{3}$ for short fetch lengths $(1 \mathrm{~m})$ and low vertical mixing to larger fetch lengths $(5 \mathrm{~m})$ and stronger vertical mixing, respectively, from ambient $\mathrm{O}_{3}$ levels of $144 \mu \mathrm{g} / \mathrm{m}^{3}$. Vegetation fetch and vegetation height had the largest impact on modeled $\mathrm{O}_{3}$ reductions, suggesting large, continuous, intensive green roof designs may enhance $\mathrm{O}_{3}$ reductions in building ventilation air.

\section{Keywords:}

$\mathrm{O}_{3}$ dry deposition; Urban vegetation; Green roof; Pollutant sink; Pollutant mitigation; Ventilation air supply 


\subsection{INTRODUCTION}

The benefits of green roofs (also referred to as vegetated roofs or ecoroofs) may include a variety of environmental and economic benefits, such as reducing storm-water runoff, improving rooftop membrane longevity, energy savings, and reducing urban heat island effects.[1-5] A green roof is defined as a vegetated continuous rooftop that may have short grass, tall herbaceous plants, and occasionally shrubs and/or small trees. [6] Cities such as Stuttgart, Copenhagen, Toronto, and others, including Portland, have all mandated green roofs be implemented for large commercial buildings.[7] Modeling studies have characterized urban pollutant deposition to vegetation, including green roofs and urban forests, and report benefits for urban air quality.[8-11] Green roof impacts on urban air quality are expected to be less than that of street level vegetation.[6] Sicard et al. [12] reviewed ozone $\left(\mathrm{O}_{3}\right)$ removal by urban vegetation and found that $\mathrm{O}_{3}$ removal by urban forests $\left(3.4 \mathrm{~g} \mathrm{~m}^{-2}\right.$ year $^{-1}$ on average $)$ was greater than removal by green roofs $\left(2.9 \mathrm{~g} \mathrm{~m}^{-2}\right.$ year ${ }^{-1}$ on average). However, green roofs are often placed in close proximity to building ventilation systems. This includes outdoor air intakes to the building, often as part of heating, ventilation, and air conditioning (HVAC) systems known as rooftop units (RTUs). If a green roof is installed in proximity to an RTU, human exposure to air pollution may be altered since outdoor ventilation air can interact with vegetation before entering the building.[13]

Tropospheric $\mathrm{O}_{3}$ is an outdoor air pollutant that is known to be a harmful pollutant for vegetation and human health and has been shown to be increasing in urban environments over the last few decades [14-19]. Dry deposition of $\mathrm{O}_{3}$ to green roofs could act as a removal mechanism effectively treating air that is brought indoors. While the removal of $\mathrm{O}_{3}$ is beneficial for human health, $\mathrm{O}_{3}$ interaction with vegetation and/or biogenic volatile organic compounds (BVOCs) may produce harmful and/or irritating compounds that should also be considered.[20-22] Recent work demonstrates the potential influence of vegetation, including that present on building rooftops, on local $\mathrm{O}_{3}$ concentrations. BVOC emission capacity and $\mathrm{O}_{3}$ formation was studied by Baraldi et al. [23] and they found that the potential for green roof vegetation to contribute to net $\mathrm{O}_{3}$ formation was very low. Carslaw et al.[13] modelled the role of outdoor BVOCs in the 
formation secondary organic aerosols (SOAs) inside office buildings, finding ambient biogenic emissions where $\mathrm{O}_{3}$ concentrations are elevated contribute substantially to indoor particulate matter. Another largescale modelling effort by Yang et al.[6] characterized urban $\mathrm{O}_{3}$ fluxes to green roofs in the Chicago area and attributed $\sim 50.5 \mathrm{~kg} \mathrm{ha}^{-1} \mathrm{yr}^{-1}$ of $\mathrm{O}_{3}$ removal to green roofs. Finally, a recent study showed differences in loadings on filters taken from RTUs sited in green vs. white membrane roofs. Measured $\mathrm{O}_{3}$ removal efficiency to a used HVAC filter taken from the green roof (26\%) was higher than that of used white roof (10\%) and that of an unused filter (15\%).[24]

Currently, there is scant empirical research on air-pollutant dynamics and surface resistances of vegetated green roofs, and urban roof surfaces more generally. The present study addresses this gap by reporting results from 1) field measurements of $\mathrm{O}_{3}$ dry deposition at the neighborhood scale in an urban environment which contains a green roof and urban greenery, 2) chamber $\mathrm{O}_{3}$ flux experiments to green roof and substrate (engineered growing media from the roof) samples taken from the field-site green roof, and 3) a 2-D advection-diffusion model that applies field and laboratory surface resistance measurements at the scale of a building rooftop to determine if green roofs meaningfully impact local $\mathrm{O}_{3}$ levels near building outdoor air supply.

\subsection{MATERIALS \& METHODS}

\subsection{Field Measurement}

A field measurement campaign was conducted to measure $\mathrm{O}_{3}$ fluxes in an urban area containing vegetation typical of an urban environment. The field campaign took place from 24 August 2017 to 7 September 2017 in Portland, OR, USA during a period of high temperatures and $\mathrm{O}_{3}$ concentrations. The period included a major regional wildfire from 2 September 2017 to 7 September 2017 which reduced the dataset. Regional wildfires persisted for two months after the data collection period. The field campaign was designed considering the limitations of the surrounding site, instrumentation, and access to rooftop 
where sampling occurred. Site meteorology was considered and used to calculate the $\mathrm{O}_{3}$ flux footprint.[25] The method used to measure $\mathrm{O}_{3}$ fluxes was the atmospheric gradient method (AGM).[26]

\subsubsection{Field Flux Calculations:}

The heterogeneous interaction of $\mathrm{O}_{3}$ and the green roof can be modelled as a downward flux $\left(F_{O}\right.$,

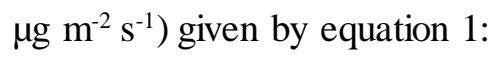

$$
F_{O}=v_{d} \times C_{\mathrm{o}}
$$

where $v_{d}$ is a constant of proportionality known as the deposition velocity $(\mathrm{m} / \mathrm{s})$ and $C_{\mathrm{o}}$ is the concentration $\left(\mu \mathrm{g} / \mathrm{m}^{3}\right)$ of $\mathrm{O}_{3}$ at a measurement height.

A multi-layer big leaf model [27-29] separates the deposition velocity into transport and surface resistances shown in equation 2 :

$$
v_{d}=\frac{1}{r_{t}}=\frac{1}{r_{a}+r_{b}+r_{c}}
$$

where $r_{t}$ is the total resistance $(\mathrm{s} / \mathrm{m}), r_{a}$ is the aerodynamic resistance $(\mathrm{s} / \mathrm{m}), r_{b}$ is the quasi-laminar boundary layer resistance $(\mathrm{s} / \mathrm{m}), r_{c}$ is the canopy or surface resistance $(\mathrm{s} / \mathrm{m})$, and all other terms as defined previously. Formulations for $r_{a}$ and $r_{b}$ are shown in the supporting information (SI) document.

For the AGM, the only resistance assumed between the two measurement heights is the aerodynamic resistance which can be used to calculate $v_{d}$ as shown in equation 3 :

$$
F_{O}=\frac{\Delta C_{\mathrm{o}}}{r_{a}\left(z_{1}: z_{2}\right)}=v_{d} \times C_{\mathrm{o}}
$$

where $\Delta C_{\mathrm{o}}\left(\mu \mathrm{g} / \mathrm{m}^{3}\right)$ is the change in concentration between an upper position, $z_{1}(\mathrm{~m})$ and the lower position, $z_{2}(\mathrm{~m}), r_{a}\left(z_{1}: z_{2}\right)(\mathrm{s} / \mathrm{m})$ is the aerodynamic resistance between $z_{1}$ and $z_{2}$, and all other terms are as defined previously.

\subsubsection{Site description:}


Ozone and meteorological measurements occurred on the rooftop of a big-box retail store in north Portland, OR. The building includes a $3,440 \mathrm{~m}^{2}$ rooftop that is split between a green roof and white membrane roof, shown in Figure 1a, with RTUs and air handling units (AHUs) operating periodically. The predominant plants on the rooftops were sedums, primarily SedumTakesimense and Sedum Kamtschaticum with seasonal variations in species. During the measurement period, the rooftop vegetation was stressed due to an abnormally dry summer season due to high temperatures and low rainfall during the spring season. The field site is surrounded to the south primarily by urban "hard" surfaces and to the north and northwest primarily by vegetated surfaces and urban greenery. A major interstate highway (I-5) is present to the west of the building. This highway is located $\sim 1000$ meters from the measurement location and its impact on site air quality is expected to be modest as pollution from traffic typically reaches urban background levels within $\sim 500$ meters.[30]

Shown in Figure $1 \mathrm{~b}$ is a schematic of the field experimental set-up. A three-dimensional sonic anemometer (Campbell Sci., CSAT3) measured velocity and temperature fluctuations at a measurement rate of $10 \mathrm{~Hz}$. The sonic anemometer was placed such that the centre of axis in the $\mathrm{z}$ direction is 8 meters above the surrounding ground-level. The instrument was oriented parallel to the edge of the rooftop where the $y$-direction was perpendicular to the back vertical wall of the building. The $y$-direction was aligned to $303^{\circ}$ wind direction. A single $\mathrm{O}_{3}$ monitor (2B Tech, 106L) measured $\mathrm{O}_{3}$ concentration at heights of $8 \mathrm{~m}$ and $7 \mathrm{~m}$ every $10 \mathrm{~s}$, recorded as one-minute averages. The heights were chosen considering the rooftop height, $6.4 \mathrm{~m}$, and the tripod height, approximately $1.75 \mathrm{~m}$. An automated Swagelok switching valve (SS43ZF2-41DCZ) controlled by a timer/controller (Sestos B3S-2R-24) alternated between the heights at 10min interval. The concentration and meteorological data is averaged over a 30-min period.[31] All monitoring equipment and the switching valve were enclosed in a ventilated, acrylic enclosure to protect the instruments from wind, rain, and heat. A heating mat was wrapped around the inlet lines to prevent condensation in the lines. As will be discussed, we observed higher variability in $\mathrm{O}_{3}$ measurements during some morning periods that we speculate resulted from high water vapor mixing ratios and/or condensation 
in the sampling line. Other studies have shown pollutant gradients measured with the AGM in the morning have higher uncertainties relative to other techniques.[31]

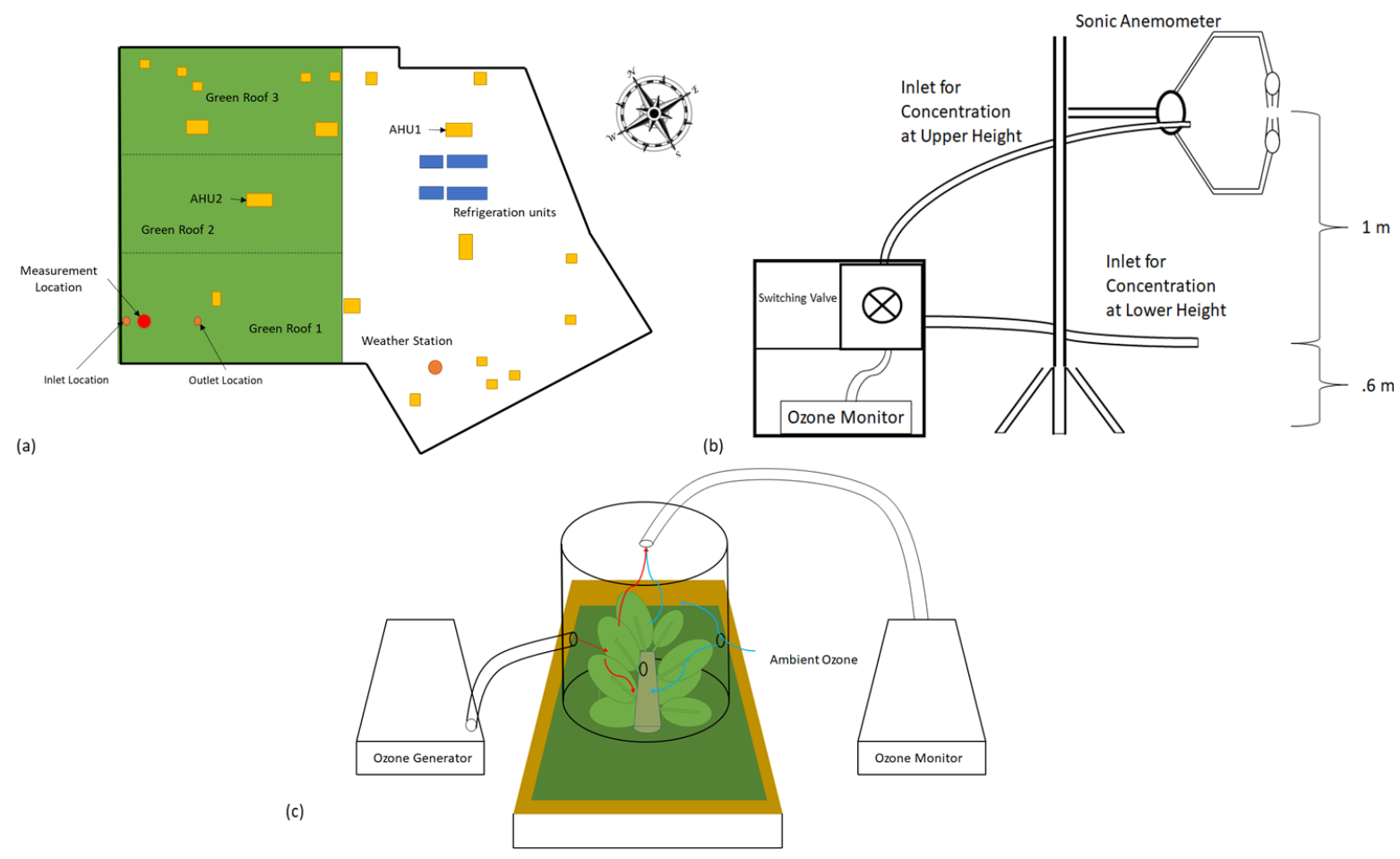

Figure 1. (a) Rooftop outline of the green roof field site (b) Field set up of ozone fluxes and meteorological data on the rooftop site, note elevations are relative to the rooftop surface (c) Chamber set up of isolated ozone fluxes over green roof material.

\subsubsection{Measurement of Concentration Gradient}

Velocity fluctuations in the $\mathrm{x}, \mathrm{y}$ and $\mathrm{z}$-direction were used to determine the friction velocity, similar to the approach by Bryan et al.[32], where shear stresses measured by a sonic anemometer are used to determine the wall shear stress and subsequently the friction velocity. Temperature fluctuations in combination with velocity fluctuations in the z-direction are used to determine heat flux over the rooftop. The friction velocity and heat flux are key components for calculating the aerodynamic and boundary layer resistance, $r_{a}$ and $r_{b}$, used in the AGM.[33-35]

The AGM requires measurement of $\mathrm{O}_{3}$ concentration at two heights as well as the three orthogonal velocity fluctuations and the temperature fluctuations at the upper height. These data enable the calculation of time-averaged surface fluxes, typically over periods of tens of minutes. The flux associated with the 
AGM will be to a large area that, in this study, includes both urban greenery and urban structures (see section 3.1). We selected for periods where $\mathrm{O}_{3}$ flux can be attributed predominantly to urban vegetation; occurring when wind direction was between $273^{\circ}$ to $333^{\circ}$. Although selected for surface vegetation, the flux cannot be attributed fully to urban vegetation as that would only be met in ideal conditions, such as an infinite vegetated fetch. The crosswind integrated footprint is calculated using MATLAB code [25] on MATLAB R2016b and discussed in further detail in section 3.1. A second $\mathrm{O}_{3}$ monitor (2BTech, Model 106-L) and switching valve assembly similar to that described previously measured $\mathrm{O}_{3}$ concentrations at two locations on the green roof, both at a height of $1 \mathrm{~m}$ above the rooftop. These locations served as "inlet" and "outlet" points, respectively, that enabled direct measurement of the impact of the green roof on $\mathrm{O}_{3}$ levels in air traversing a known distance of green roof.

The time-series $\mathrm{O}_{3}$ concentrations alternated across the two heights and required processing to align the time-series data to a common measurement time for each 30-minute period. A linear interpolation was used similar to previous studies.[36] As in Stutz et al.[36], measurements of gradients greater than 35\% across each averaging period were neglected. The criterion used for stationarity is to determine if there is a difference between the average of momentum fluxes of six continuous 5-minute periods and a 30-minute average during the same period. If the difference is less than $30 \%$, the data is considered high quality.[37] In our case, all data is under $30 \%$.

\subsection{Chamber Flux Experiments}

Chamber experiments, shown in the schematic in Figure 1c, were conducted to calculate $\mathrm{O}_{3}$ surface flux specific to the vegetation from the rooftop via experiments similar to those conducted by Simmons and Colbeck.[38] Two cylindrical chambers $($ diameter $=20.3 \mathrm{~cm}$, height $=20.3 \mathrm{~cm})$ were constructed from acrylic: an open-bottom chamber and a closed-bottom control chamber following a similar design as Almand-Hunter et al. [39] Tests were conducted by measuring the decay of $\mathrm{O}_{3}$ following elevation to $\sim 350$ ppb using a corona discharge $\mathrm{O}_{3}$ generator (Eleoption, B01M8IC3EK). An $\mathrm{O}_{3}$ monitor (2B Tech, 106L) 
was used to measure $\mathrm{O}_{3}$ concentrations in the chamber every 10 seconds. The dry deposition velocity, $v_{d}$, was calculated by a numerical solution to a mass-balance on the chamber, similar to the approach taken by Gall et al.[40] A closed-bottom chamber was used to measure background dry deposition velocities to acrylic chamber surfaces. The air-exchange rate for the chambers was measured using a $\mathrm{CO}_{2}$ tracer decay experiment in the absence of vegetation and averaged $0.196 \mathrm{~min}^{-1}$.

One $25.4 \mathrm{~cm}$ x $25.4 \mathrm{~cm}$ green roof sample and a soil substrate material, removed from the rooftop, were selected for laboratory measurements of $\mathrm{O}_{3}$ surface flux. Soil moisture was varied by adding and mixing incrementally higher water to the green roof and soil substrate trays and allowing them to saturate overnight. The resulting volumetric water contents determined using a soil moisture sensor (Decagon, EC5) were $0.12,0.18$, and $0.25 \mathrm{~m}^{3} \mathrm{~m}^{-3}$ for the green roof samples, and $0.03,0.04$, and $0.07 \mathrm{~m}^{3} \mathrm{~m}^{-3}$ for substrate sample replicates. Light conditions were varied between 1.2, 14.3 and $100.9 \mu \mathrm{mol} \mathrm{m}^{-2} \mathrm{~s}^{-1}$ for the green roof

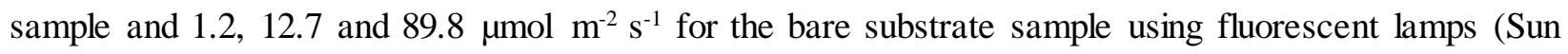
Systems, New Wave T5 and SunLight Supply, New Wave T5). The air temperature and relative humidity (Onset, S-THB-M002), substrate temperature (Onset, S-TMB-M006), photosynthetically active radiation (PAR) (Onset, S-LIA-M003), and solar radiation (Onset, S-LIB-M003) were also monitored throughout the various experiments. The PAR and solar radiation sensors were placed beside the chamber on top of the substrate. Tests of PAR inside vs. outside the chamber indicate no measurable difference in PAR due to the acrylic chamber. Additional experiments were conducted to separate the boundary layer resistance by using potassium iodide (KI), similar to Almand-Hunter et al. [39] and Pape et al. [41]. However, in these tests, we coated the vegetation itself with a KI solution (100 grams of pure KI dissolved in $125 \mathrm{~mL}$ of deionized water) and then immediately conducted an $\mathrm{O}_{3}$ decay test. The inverse of the deposition velocity calculated to the green roof sample coated with KI provides an estimate of boundary layer resistance and the surface resistance was calculated as shown in Equation 4:

$$
r_{c}=\frac{1}{v_{d}}-\frac{1}{v_{d K I}}
$$


where $v_{d}$ is the $\mathrm{O}_{3}$ dry deposition velocity for the green roof sample and $v_{d K I}$ is the $\mathrm{O}_{3}$ dry deposition velocity of the sample coated with KI.

\subsection{Rooftop Advection-Diffusion Model}

The measured parameters from the field and laboratory measurements were used in an advectiondiffusion model to assess the impacts of rooftop and meteorological variables on $\mathrm{O}_{3}$ dry deposition at the rooftop scale, shown in Figure 2. The model is split between an inertial surface layer (ISL) and a roughness sublayer (RS), given in equation 5 (ISL) and $6(\mathrm{RS})$ :

$$
\begin{aligned}
& \frac{\partial \overline{C_{0}}}{\partial t}=-\bar{u} \frac{\partial \overline{C_{0}}}{\partial x}-\frac{\partial}{\partial z} K_{m} \frac{\partial \overline{C_{0}}}{\partial z} \\
& \frac{\partial \overline{C_{0}}}{\partial t}=-\bar{u} \frac{\partial \overline{C_{0}}}{\partial x}-\left[\sum_{i=1}^{n} \frac{v_{d i} A_{i}}{V}\right] \times \overline{C_{0}}
\end{aligned}
$$

where $\overline{C_{0}}$ is the mean $\mathrm{O}_{3}$ concentration, $\bar{u}$ is the mean velocity, $K_{m}$ is the eddy diffusivity coefficient for mass, $v_{d i}$ is the deposition velocity, $A_{i}$ is the area of the deposition surface, and $V$ is the control volume.

A numerical analysis was performed where grid spacing was discretized non-uniformly so that the treatment of the roughness sublayer (RS) occurred in one layer while the inertial surface layer (ISL) was split into multiple layers over the rooftop. The RS is a layer in which the constant flux term does not hold, instead the deposition velocity, $v_{d i}(\mathrm{~m} / \mathrm{s})$, is used characterize the downward flux.[33] The height of the RS is typically assumed to be somewhere between 2 to 5 times the height of the roughness elements, for our model, we chose 3 times the height of the roughness elements.[42] To simplify the discretization further, the area for deposition was assumed to be the bottom surface area of the control volume, which allowed for the reduction of the bulk deposition term as shown in equation 7 :

$$
\frac{v_{d i} \times A_{i}}{V}=\frac{v_{d i}}{h}
$$

where $h$ is the height of the control volume (m), and all other terms as described previously. 
The model was run until steady state; defined similarly to Coleman et al.[43] as an $\mathrm{O}_{3}$ level changing less than 2 ppb over 20 minutes. A grid sensitivity study was performed to define a gridindependent solution, occurring at an x-y grid spacing of 125 x 125 nodes.

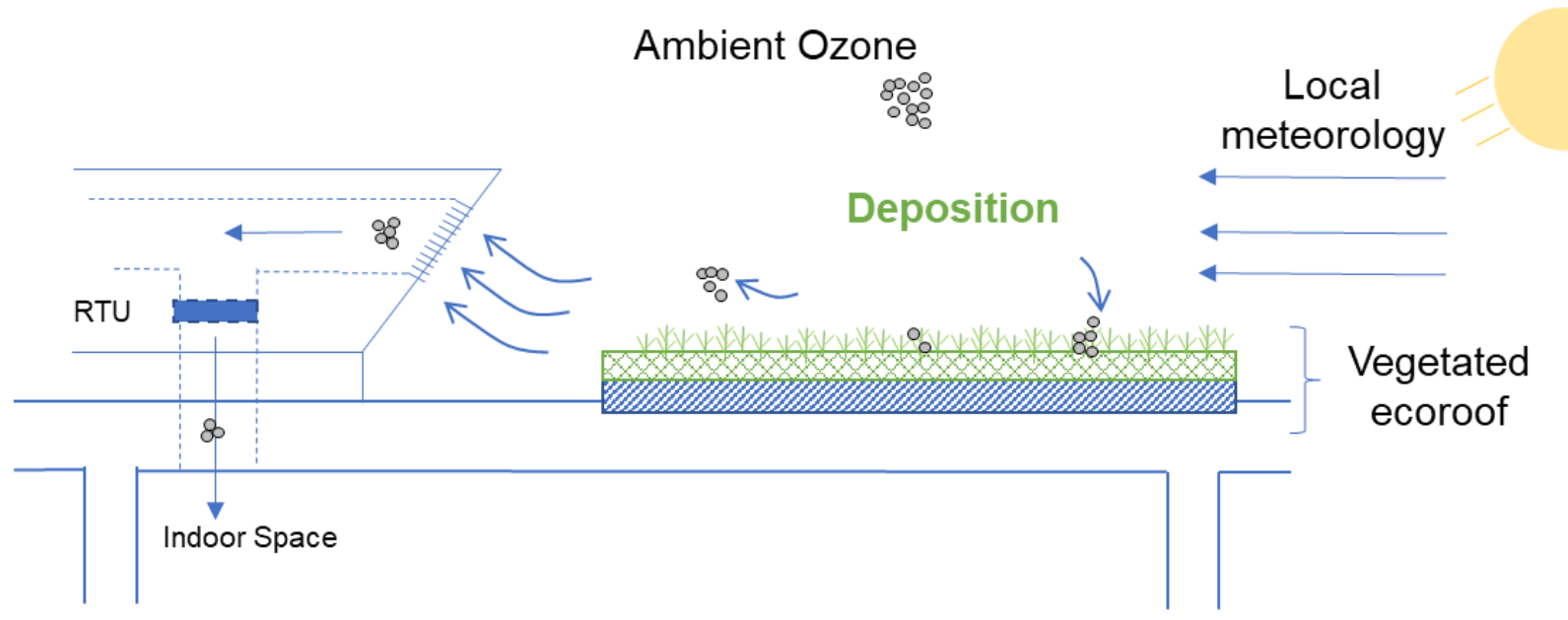

Figure 2: A model diagram of the interaction between ozone and the green roof due to local meteorological conditions and surface chemistry. Note that the grey circles represent ozone.

\subsubsection{Parametric Study}

A parametric study using measured parameters from the field and laboratory tests assessed model sensitivity using green roof fetch length, green roof surface element (vegetation) height, friction velocity, heat flux and surface resistance. These parameters were varied between a low, medium and high or the $10^{\text {th }}$ $50^{\text {th }}$, and $90^{\text {th }}$ percentiles shown in Section 3.3. Friction velocity and heat flux, in combination with the RS height, was used to calculate the aerodynamic and boundary layer resistance for the rooftop scale. A base case was set as either the middle value or the $50^{\text {th }}$ percentile of the measured values. High and low cases were changed independently from the measured base case.

The column of concentration values at the edge of the control volume was assumed to reflect concentrations that would enter a hypothetical RTU. The RTU itself was not modeled due to the complex geometry and discontinuity in scale from the vegetated elements. The concentration at a height of 0.75 meters above the rooftop within this column is used to assess potential impacts of the green roof on outdoor ventilation air. This is the measured height of RTU outdoor air intakes at our field site. Note the ASHRAE 
62.1-2016 sets the minimum air intake distance to be $0.30 \mathrm{~m}$ from a 'Roof, landscaped grade, or other surface directly below intake'.[44]

\subsubsection{Sensitivity Analysis}

Model uncertainty was characterized by sensitivity indices, $S I_{C_{0.75}}$, and subsequently the elasticity indices $[40,45], E I_{C_{0.75}}$ calculated at an elevation above the rooftop of 0.75 , as shown in equations 8-9:

$$
\begin{aligned}
& S I_{x-C_{0.75}}=\frac{C_{0.75, S S}\left(x_{0}+\Delta x\right)-C_{0.75, S S}\left(x_{0}-\Delta x\right)}{2 \Delta x} \\
& E I_{x-C_{0.75}}=\frac{x_{0}}{C_{0.75, S S}\left(x_{0}\right)} S I_{x-C_{0.75}}
\end{aligned}
$$

where $x$ is the input parameter, $x_{0}$ is the base case parameter and $\Delta x$ is the change in the input parameter and the parameter $C_{0.75, S S}$ is the steady-state concentration at a height $0.75 \mathrm{~m}$ above the rooftop at the edge of the control volume (the "outlet" of a hypothetical fetch of green roof) . The elasticity index, $E I_{C_{0.75}}$ shows how a single parameter affects the $C_{0.75, S S}$. Note that if the $E I_{C_{0.75}}$ is positive, increases in the variable lead to increases in the $C_{0.75, S S}$, and the opposite if the $E I_{C_{0.75}}$ is negative.

\subsection{RESULTS AND DISCUSSION}

This study quantifies the transport and dry deposition of $\mathrm{O}_{3}$ to both urban vegetation and green roofs; data from these measurements are then used to model the influence of the roof vegetated surface on $\mathrm{O}_{3}$ dry deposition on $\mathrm{O}_{3}$ levels entering a hypothetical RTU surrounded by a green roof.

\subsection{Field Results}

Within the study period, we selected meteorological and $\mathrm{O}_{3}$ data such that the prevailing wind direction was northwesterly, where upwind surfaces are predominantly urban vegetation. This left a twoday period in which $\mathrm{O}_{3}$ surface fluxes are attributable to urban vegetation, shown in Figure 3a. Also shown for comparison is data collected at the local department of environmental quality (DEQ) southeast Lafayette 
(SEL) location, located approximately $12 \mathrm{~km}$ from our site. The $\mathrm{O}_{3}$ concentration profile during the twoday period reported by the DEQ matched well with the field data $\left(r^{2}=0.93\right)$.

Field measurements occurred from $24^{\text {th }}$ of August 2017 to $7^{\text {th }}$ of September 2017. From $24^{\text {th }}$ of August 2017 to $25^{\text {th }}$ of August 2017, $\mathrm{O}_{3}$ concentration data was highly variable for much of the daytime and this period is impractical for flux measurements. The wind selection criteria, in conjunction with the uncertainty and gradient selection criteria reduced the amount of data during the periods $29^{\text {th }}$ of August 2017 to $1^{\text {st }}$ of September 2017, to less than $30 \%$ and deemed not continuous enough to represent daytime fluxes over vegetation. Finally, a regional fire in the Columbia Gorge area that caused ashing and high particulate matter levels made the last six days, $2^{\text {nd }}$ of September 2017 to $7^{\text {th }}$ of September 2017, of the twoweek field campaign unsuitable. This left a period between $26^{\text {th }}$ of August 2017 to $28^{\text {th }}$ of August 2017 of meteorological conditions and $\mathrm{O}_{3}$ concentration measurements suitable for assessment of $\mathrm{O}_{3}$ fluxes to urban vegetation. Although this study period was short, prior surface flux studies suggests that short periods may be used to evaluate the impacts of surfaces on local pollutant concentrations. Stutz et al. [36] determined the correlation between $\mathrm{NO}_{2}$ deposition and $\mathrm{HONO}$ emission over grasslands in an urban environment using two separate, two-day field measurements. Dugas et al. [46] measured sensible and latent heat flux over a two day period in April, 1989 and found the measured and calculated fluxes were comparable but significantly higher than the eddy correlation measurements during the same period. Craine, Weding and Chapin [47] studied the shade and shade-sun effects on $\mathrm{CO}_{2}$ fluxes through two-day periods and found that shading reduced $\mathrm{CO}_{2}$ fluxes by $40 \%$. 
(a)

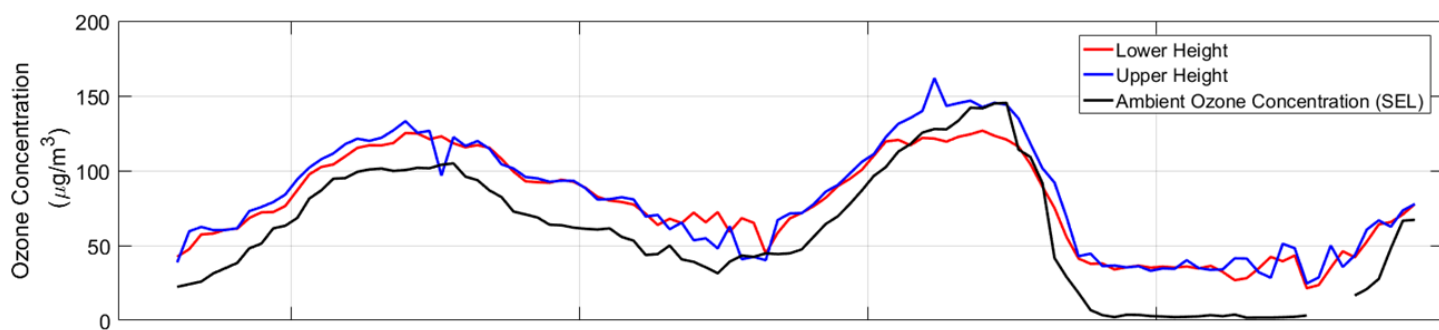

(b)

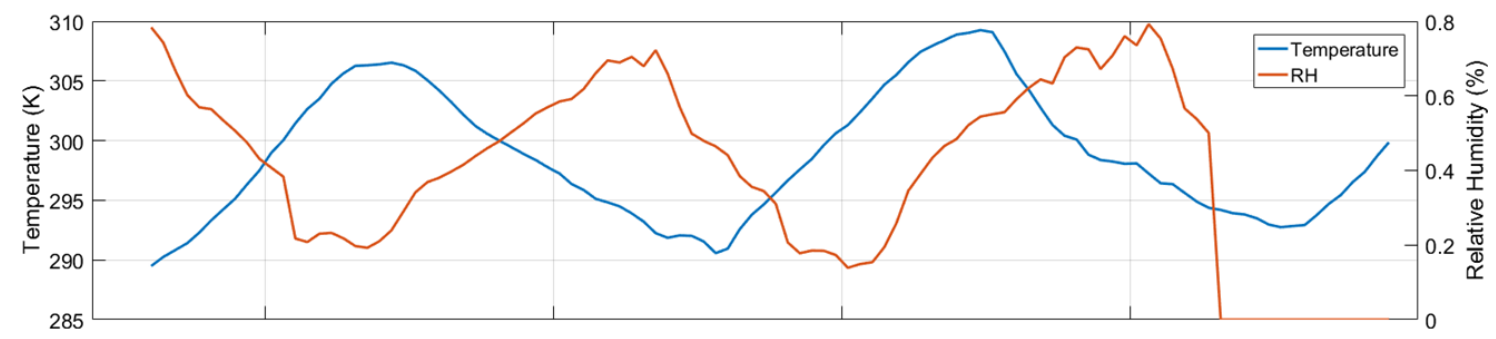

(c)
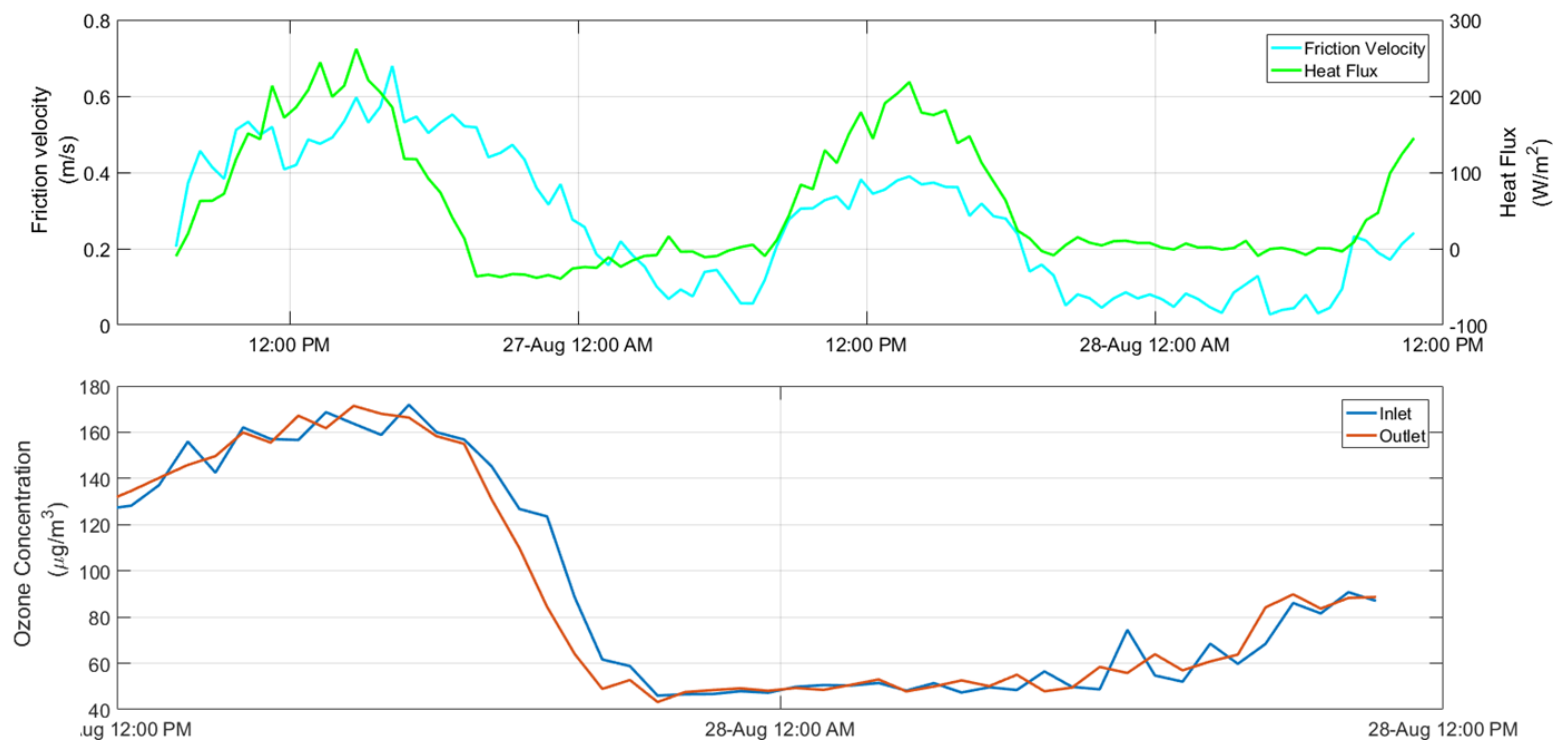

Figure 3. (a) Ozone concentration measurements for a two-day period at the rooftop location and the Department of Environmental Quality South-East Lafayette (SEL) location (we observe high uncertainty

in early morning $\mathrm{O}_{3}$ measurements due to low $\mathrm{O}_{3}$ levels and potential moisture interference) (b)

Temperature and relative humidity measurements on the rooftop (c) Friction velocity and heat flux measurements (d) Ozone concentration measurements of 'inlet' to the green roof and an 'outlet' measurement approximately 10 meters downwind on the rooftop

Site temperature and RH are shown in Figure 3b. Figure 3c shows the micrometeorological data from the previously described field data subset. During the afternoon period on both days, the atmosphere was unstable, but during late evenings, nights and early mornings, the atmosphere was stable or neutral as determined by calculation of the stability parameter using the Obukhov length. Figure $3 \mathrm{~d}$ shows 24 hours of measurements at two locations across the green roof at constant height above the rooftop. One location was on the north edge of the green roof and a second location 10 meters to the South (see Figure 1a). Note 
that the period shown in Figure 3d results in airflow that moves from the "inlet" location to the "outlet". We observed that "inlet" and "outlet" levels were generally within instrument uncertainty $\left( \pm 4.2 \mu \mathrm{g} / \mathrm{m}^{3}\right.$, added in quadrature), implying, at best, modest effects of the green roof on $\mathrm{O}_{3}$ levels at heights typical of building outdoor air intakes for the field conditions during which our measurements were made.

The green roof was surrounded by contrasting environments, with vegetated surfaces to the North and urban structures to the South, shown in Figure 4a. The wind direction and frequency determined from the sonic anemometer (Figure 4b) is selected for periods of flow over urban vegetation (Figure 4c), ranging from wind direction of $273^{\circ}$ to $333^{\circ}$. After application of the wind direction and gradient selection criteria, approximately 42 percent of concentration and meteorological measurements, including periods of high $\mathrm{O}_{3}$ concentration during daytime, was maintained. For the height of the instrument and the measurement technique used, the effective flux footprint was calculated, similar to that measured by Velasco et al. [48], shown in Figure 4d. The effective crosswind integrated flux footprint shows more than $80 \%$ of the upwind fetch corresponds to urban greenery.

(a)

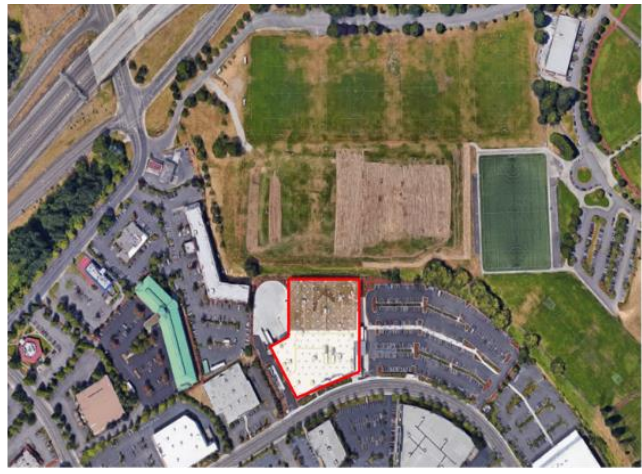

(c)

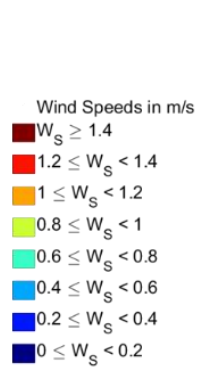

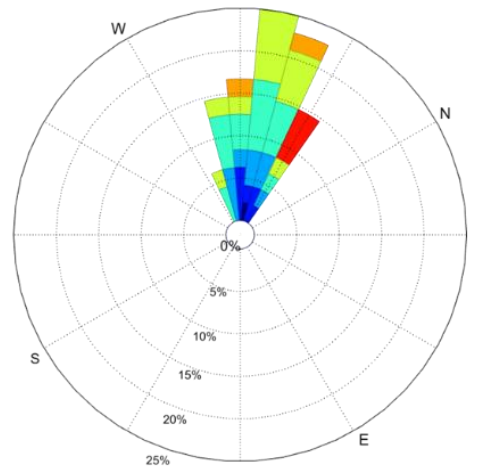

Wind Speeds in $\mathrm{m} / \mathrm{s}$ $\square W_{\mathrm{S}} \geq 3$ $2.5 \leq W_{\mathrm{S}}<3$ $2 \leq \mathrm{W}_{\mathrm{S}}<2.5$ $\square \leq W_{S}<2$ $1 \leq W_{\mathrm{S}}<1.5$ $0.5 \leq W_{S}<1$ $0 \leq \mathrm{W}_{\mathrm{S}}<0.5$

(b)
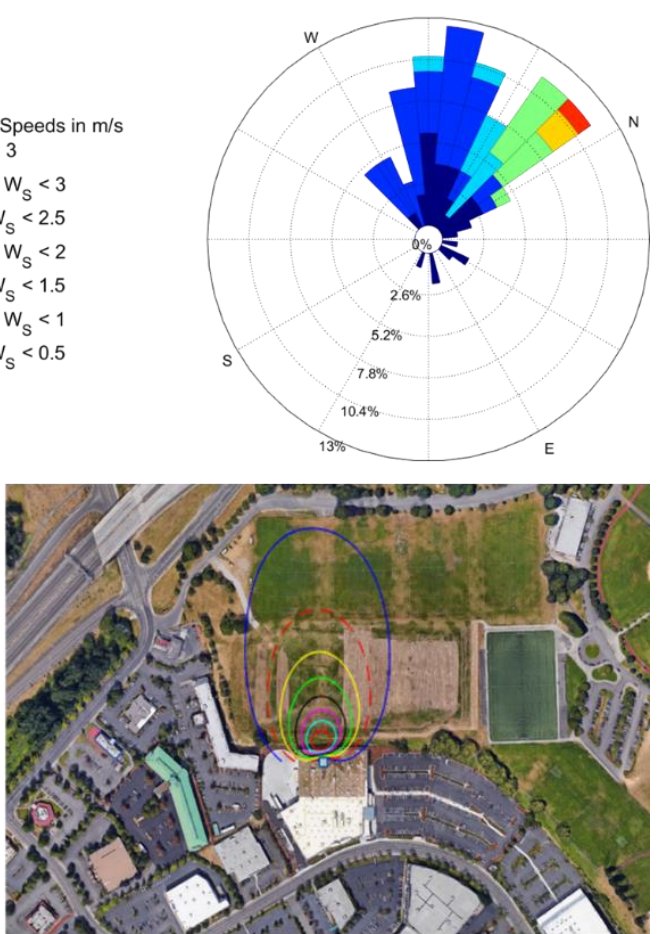
Figure 4. (a) Rooftop field location with green and white rooftop outlined in red (b) Wind rose of the micrometeorological data pre-selection criteria across the two-day period (c) Wind rose of the micrometeorological data after selecting for periods of flow over urban vegetation within the two-day period (d) Cross-wind integrated flux footprint using software provided by Kljun at the Institute of

Atmospheric and Climate Science in Zurich, Switzerland.

The concentration flux can be calculated using the AGM given in equation 3 and subsequently a deposition velocity can be determined. Note that during early morning periods, higher uncertainty in $\mathrm{O}_{3}$ measurement was observed, described further in the supporting information. Figure 5a shows the dry deposition velocity over the two-day period. During the first day, the difference between the upper and lower concentrations is small, resulting in generally lower $v_{d}$ values. On the second day, there existed periods of high $v_{d}$. In the early morning periods, we observed several measurements of negative $v_{d}$ we expect due to aforementioned challenges with high $\mathrm{RH}$. The mean $v_{d}$ across measurable events during this period is $0.55 \mathrm{~cm} / \mathrm{s}$, on the higher end of the range expected for dry deposition over land and grassland $(0.1$ $-0.5 \mathrm{~cm} / \mathrm{s}$ ) [49-51] but approximately the same range as those reported by Zhang et al. [52] for summer grass and summer mixed forest. The $10^{\text {th }}$ and $90^{\text {th }}$ percentile of $v_{d}$ is $0.004 \mathrm{~cm} / \mathrm{s}$, and $1.7 \mathrm{~cm} / \mathrm{s}$ respectively. The $90^{\text {th }}$ percentile is a relatively high value and could result from the AGM measurement technique used, which is known to overestimate dry deposition in the roughness sublayer by approximately a factor of two.[33] However, there is precedence of measured dry deposition velocities for foliage in this range.[53] These measurements represent, to our knowledge, the first estimate of $\mathrm{O}_{3}$ dry deposition to urban greenery specifically and appear generally in-line with measurements of $\mathrm{O}_{3}$ dry deposition to other vegetation. 
(a)

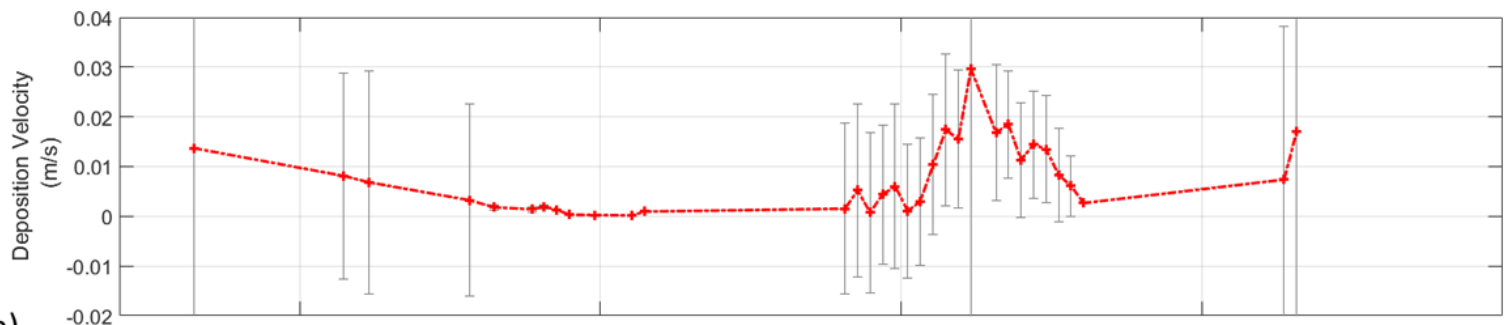

(b)

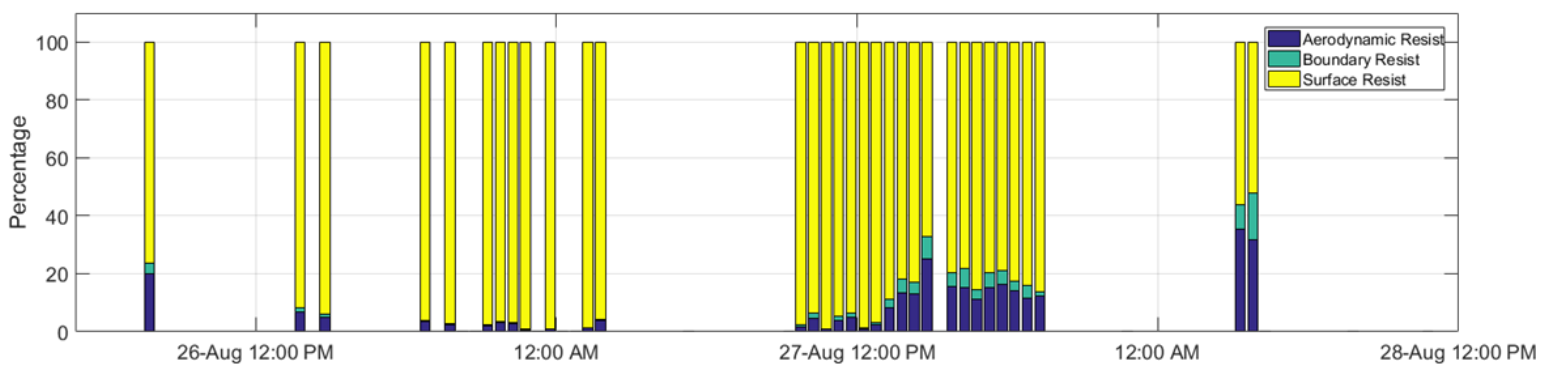

(c)
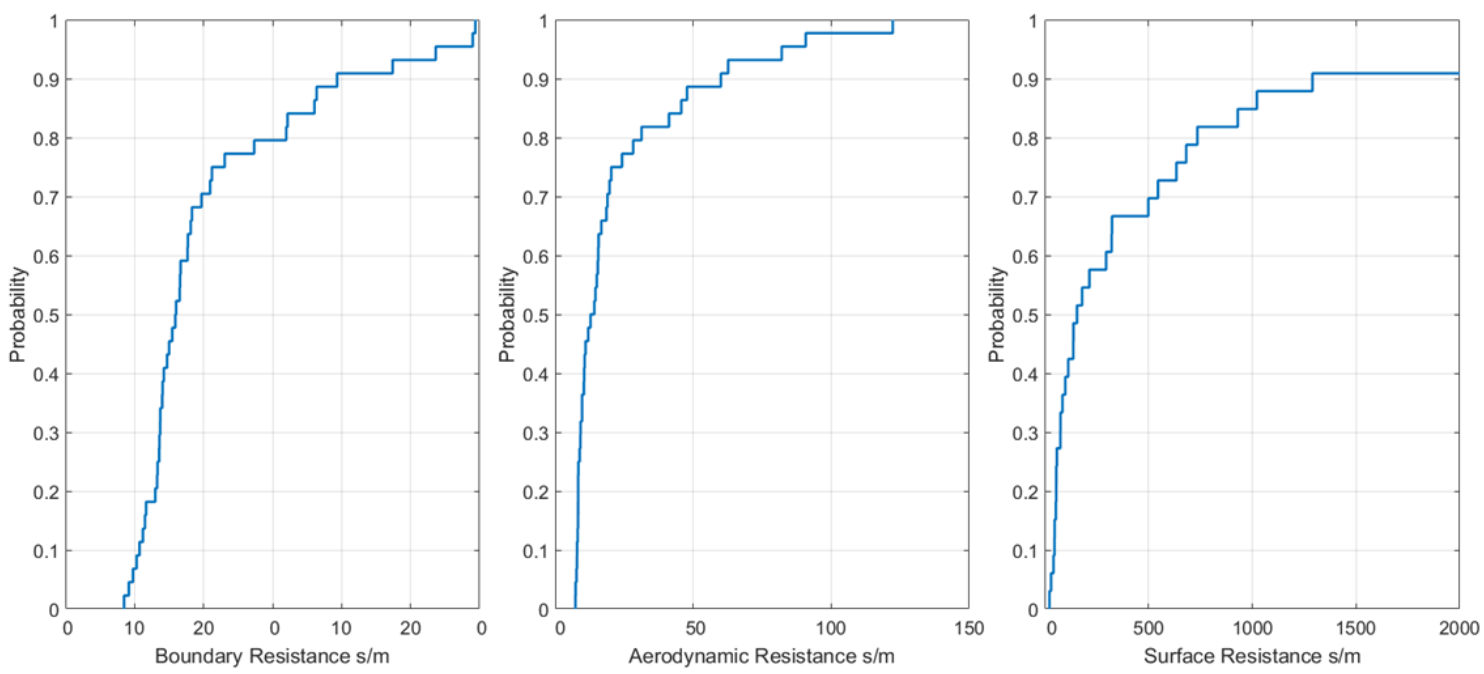

Figure 5. (a) Ozone dry deposition velocities to urban greenery and green roofs over a two-day period in the summer of 2017. The dashed red line is the measured dry deposition velocity and the gray is the propagated uncertainty (some uncertainties are large and limit interpretation of $v_{d}$ trend, so a fixed axis was assigned) (b) Surface resistance to $\mathrm{O}_{3}$ of urban greenery for a two-day period in the summer of 2017 (c) Cumulative distribution functions of the three resistances.

Over periods of measurable resistance, the $\mathrm{O}_{3}$ surface resistance is roughly an order of magnitude greater than aerodynamic and boundary layer resistance. On the second day, during periods of higher deposition velocities, the surface resistance comprises a relatively lower percentage of the total resistance. From this, it can be inferred that the surface resistance is the rate limiting step in the dry deposition process. However, the calculation of surface resistances as the remaining resistance after directly calculating aerodynamic and boundary layer resistance results in uncertainty in multiple measurements propagating to 
the surface resistance. Our best estimate of uncertainty for the turbulence data in this procedure was determined from Velasco et al.[54], who conducted an uncertainty analysis on eddy covariance data. A $\pm 20 \%$ random error and a $\pm 10 \%$ systemic error was assumed on the flux data and a total uncertainty of $60 \%$ was found on the flux measured. The required number of days to reduce the uncertainty of high frequency instruments is large and therefore cannot be compiled as seasonal trends become important.[54] Instead, a filtration was performed on the turbulence data similar to Muller et al. [55] where corrections were made for stability, wind direction and friction velocity below the threshold of $0.08 \mathrm{~m} / \mathrm{s}$. A propagation of errors was performed using \pm 1 standard deviation from the mean concentration over a 30 -minute period. This resulted in an uncertainty that was on similar scales as previously reported for gradient methods.[55]

Figure 5c shows the cumulative distribution function (CDF) for all resistances measured during the two-day period. The $10^{\text {th }}$ and $90^{\text {th }}$ percentile of the resistances are $46 \mathrm{~s} / \mathrm{m}$ and $1700 \mathrm{~s} / \mathrm{m}$ respectively with a median value of $155 \mathrm{~s} / \mathrm{m}$. The $10^{\text {th }}$ and $50^{\text {th }}$ percentiles are of similar scales to prior work presented by Weseley et al.[56] for a midsummer period with lush vegetation in various land types including urban, agricultural and various forests. The $90^{\text {th }}$ percentile is of the same scale as water, fresh snow and nonforested wetland.[56-58] Interestingly, the conditions of the plants on the rooftop and surrounding area are likely drier than reported by Weseley et al.[56] given the description of "lush" vegetation vs. the waterstressed state of vegetation here.

The variation in the magnitude of surface resistance observed in Figure $5 \mathrm{c}$ is likely due to physiological processes associated with plant phenology and/or the local meteorological conditions.[59] Plant physiological state and $\mathrm{O}_{3}$ uptake have been investigated by Wieser et al. [60], showing uptake of $\mathrm{O}_{3}$ depends on the plant stomatal conditions, interaction with the mesophyll inside the plant, as well as the outer surface and soil resistances. There is also a seasonal dependence for vegetation, as plants are more conducive to uptake of $\mathrm{O}_{3}$ in different periods of the year due to stomatal behavioral variations, primary emissions variations and others. For example, in spring, we expect the sedums to flower, therefore 
increasing their leaf area index and possibly complicating the homogenous chemistry over the green roof which could lead to greater ozone removal and perhaps a slight increase in measured ozone deposition velocities. Further exploration of the contributors to surface resistances for a common class of plants used on green roofs, sedums, is described in Section 3.2.

\subsection{Chamber Experiment Results}

Chamber experiments were performed on a green roof and bare substrate samples taken from the green roof shown in Figure 4. Light and soil moisture conditions were varied across low, medium and high conditions. The photosynthetic active radiation (PAR) was $1.2,14.3$, and $100.9 \mu \mathrm{mol} \mathrm{m} \mathrm{m}^{-2} \mathrm{~s}^{-1}$ for the green

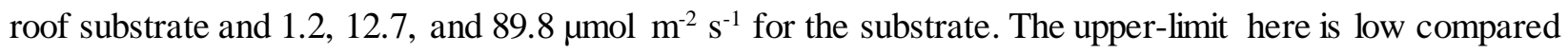
to full sunlight day in the summer in Portland, OR, and was limited by the lamps available that did not also appreciably alter the sample air and surface temperature. The moisture conditions, ranging from 0.03 to $0.07 \mathrm{~m}^{3} \mathrm{~m}^{-3}$ volumetric water content (VWC) for the soil substrate were lower than the water content of the green roof sample. Surface resistances measured in the laboratory ranged from $360 \mathrm{~s} / \mathrm{m}$ to $435 \mathrm{~s} / \mathrm{m}$ and fell in the $60^{\text {th }}-70^{\text {th }}$ percentile of field measurements. This implies that rooftop vegetation, comprised of sedum and herbaceous species, appears to have surface resistance similar to that of urban vegetation.

The green roof sample had slightly higher overall average surface resistance compared to the bare substrate sample (390 s/m for the green roof vs. $350 \mathrm{~s} / \mathrm{m}$ for the substrate), although the difference is within the range of measurement uncertainty. Higher PAR also appeared to lead to a higher surface resistance for most water conditions, again within the range of uncertainty associated with triplicate measurements (Figure 6). Plant and substrate behavior with low water content (red bar, Figure 6) are variable. Interestingly, the driest green roof sample was neither the highest nor lowest surface resistance. In contrast, the driest conditions when substrate alone was tested had the highest surface resistance, implying that substrate water content was key in limiting $\mathrm{O}_{3}$ uptake. For sedum species specifically, a wide range of stomatal conductance of water vapor has been reported under varying light, water, and temperature conditions, with the greatest resistances attributed to periods of drought stress during which the plants enter 
into the water efficient crassulacean acid metabolism, or CAM photosynthesis.[61] This is not evident in our green roof sample, which we speculate to be a result of the presence of exposed substrate in our green roof sample that offered a parallel uptake pathway to that of the high surface resistance stomatal pathways during periods of low water content. Nonetheless, further experiments for different coverage and environmental conditions are needed to specifically evaluate this potential response for sedums.
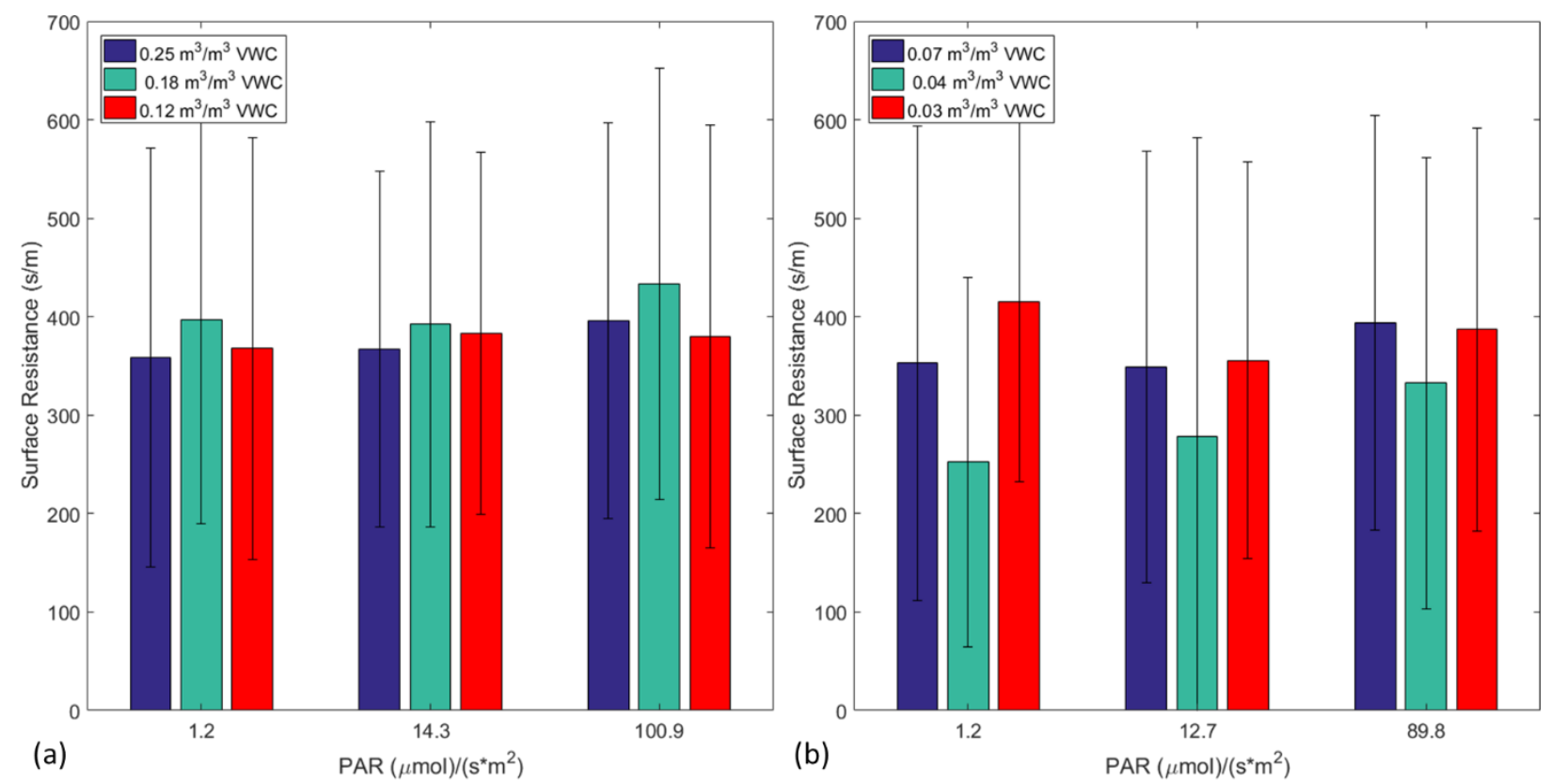

Figure 6. (a) Surface resistances from chamber experiments of varying light $\left(\mu \mathrm{mol} \mathrm{m} \mathrm{m}^{-2} \mathrm{~s}^{-1}\right)$ and soil moisture $\left(\mathrm{m}^{3} \mathrm{~m}^{-3} \mathrm{VWC}\right)$ for a sample from a green roof sample. (b) Surface resistances from chamber experiments of varying light $\left(\mu \mathrm{mol} \mathrm{m} \mathrm{m}^{-2} \mathrm{~s}^{-1}\right)$ and soil moisture $\left(\mathrm{m}^{3} \mathrm{~m}^{-3} \mathrm{VWC}\right)$ for a bare substrate sample.

\subsection{Rooftop Advection-Diffusion Model Results}

As mentioned in section 3.1, the field measurements represent a footprint that includes the green roof and surrounding vegetation. We conducted laboratory measurements that demonstrate that surface resistances of urban greenery are reasonably consistent with surface resistances measured specifically to vegetated rooftop surfaces (Section 3.2). Here, we employ the range of surface resistances measured in the lab and field studies in a model of $\mathrm{O}_{3}$ transport and removal at the rooftop scale, similar to the work done by Santiago et al.[62] for dry deposition on urban street canyons. This approach allows parameterizations determined from laboratory and field studies of $\mathrm{O}_{3}$ dry deposition to be modeled at the scale of the green 
roof. A parametric study is performed with equations 5 and 6, where five key input variables are varied according to Table 1.

Table 1: The variation in different variables for parametric study, all values taken for the percentiles shown from the field study described in the text

\begin{tabular}{|c|c|c|c|c|c|}
\hline Case & $\begin{array}{c}\text { Fetch } \\
\text { Length }(\mathrm{m})\end{array}$ & $\begin{array}{c}\text { Vegetation } \\
\text { Height }(\mathrm{m})\end{array}$ & $\begin{array}{c}\text { Friction } \\
\text { Velocity }(\mathrm{m} / \mathrm{s})\end{array}$ & $\begin{array}{c}\text { Heat Flux } \\
\left(\mathrm{W} / \mathrm{m}^{2}\right)\end{array}$ & $\begin{array}{c}\text { Surface } \\
\text { Resistance }(\mathrm{s} / \mathrm{m})\end{array}$ \\
\hline Base Case & 1 & 0.13 & 0.32 & 129 & 155 \\
\hline Case 2 & 3 & 0.13 & 0.32 & 129 & 155 \\
\hline Case 3 & 5 & 0.13 & 0.32 & 129 & 155 \\
\hline Case 4 & 1 & 0.07 & 0.32 & 129 & 155 \\
\hline Case 5 & 1 & 0.20 & 0.32 & 129 & 155 \\
\hline Case 6 & 1 & 0.13 & 0.12 & 129 & 155 \\
\hline Case 7 & 1 & 0.13 & 0.47 & 129 & 155 \\
\hline Case 8 & 1 & 0.13 & 0.32 & 11 & 155 \\
\hline Case 9 & 1 & 0.13 & 0.31 & 203 & 155 \\
\hline Case 10 & 1 & 0.13 & 0.31 & 129 & 46 \\
\hline Case 11 & 1 & 0.13 & 0.31 & 129 & 1700 \\
\hline Ideal Case & 5 & 0.20 & 0.47 & 11 & 46 \\
\hline
\end{tabular}

The base case assumes a green roof length of $1 \mathrm{~m}$. Variations include 3 and $5 \mathrm{~m}$ fetch lengths. This range of fetch length values is based on prior experience and a convenience survey of green roofs in Portland, OR to which we had access. The height of the vegetation elements for the base case is 0.13 meters, determined from measurements of the dominant species of sedum. This height was chosen based on a parallel effort at our field site in which the plant species, vegetation height, and vegetation cover were recorded over a year. Vegetation heights were observed to range from 0.07 to $0.20 \mathrm{~m}$.[63] The friction velocity, heat flux and surface resistance were determined from the median values measured from the field for the base case. The initial $\mathrm{O}_{3}$ concentration is $144 \mathrm{ug} / \mathrm{m}^{3}$, the maximum concentration measured in our field campaign. Finally, an "ideal" case is modeled using values that were $10^{\text {th }}$ or $90^{\text {th }}$ percentile values of each parameter that maximize dry deposition to the green roof.

Of interest is the concentration of $\mathrm{O}_{3}$ entering the RTU unit, therefore, we define a column of air at the outlet of the fetch as indicative of air entering building outdoor ventilation air. This column is assumed to be the final column of the control volume in the model space. An example of model output is shown in 
Figure 6a for case 3. Variations from the base case for changes in the fetch length and the "ideal" case are shown in Figure 6b.

To perform the sensitivity analysis, we compare the modeled concentration at a height of $0.75 \mathrm{~m}$ above the rooftop at the end of the fetch for each scenario. The ideal case represents a decrease in $\mathrm{O}_{3}$ levels of $\sim 1.8 \mu \mathrm{g} / \mathrm{m}^{3}$ and a lowest removal case of a decrease in $\mathrm{O}_{3}$ levels of $0.25 \mu \mathrm{g} / \mathrm{m}^{3}$. A case of fetch length of $10 \mathrm{~m}$ was also run to compare the model to field measurements of 'inlet' and 'outlet' of the fetch and presented in the SI document. The modeled reduction in ambient $\mathrm{O}_{3}$ concentration in ideal scenarios was approximately $1-1.5 \%$. This result is of similar scale to $2 \%$ local reductions in ambient $\mathrm{CO}_{2}$ concentrations due to green roofs estimated previously,[64] in close agreement with the results of this study. Sicard et al. [12] found that the average air quality improvement due to urban trees and shrubs is less than $2 \%$. 
(a)
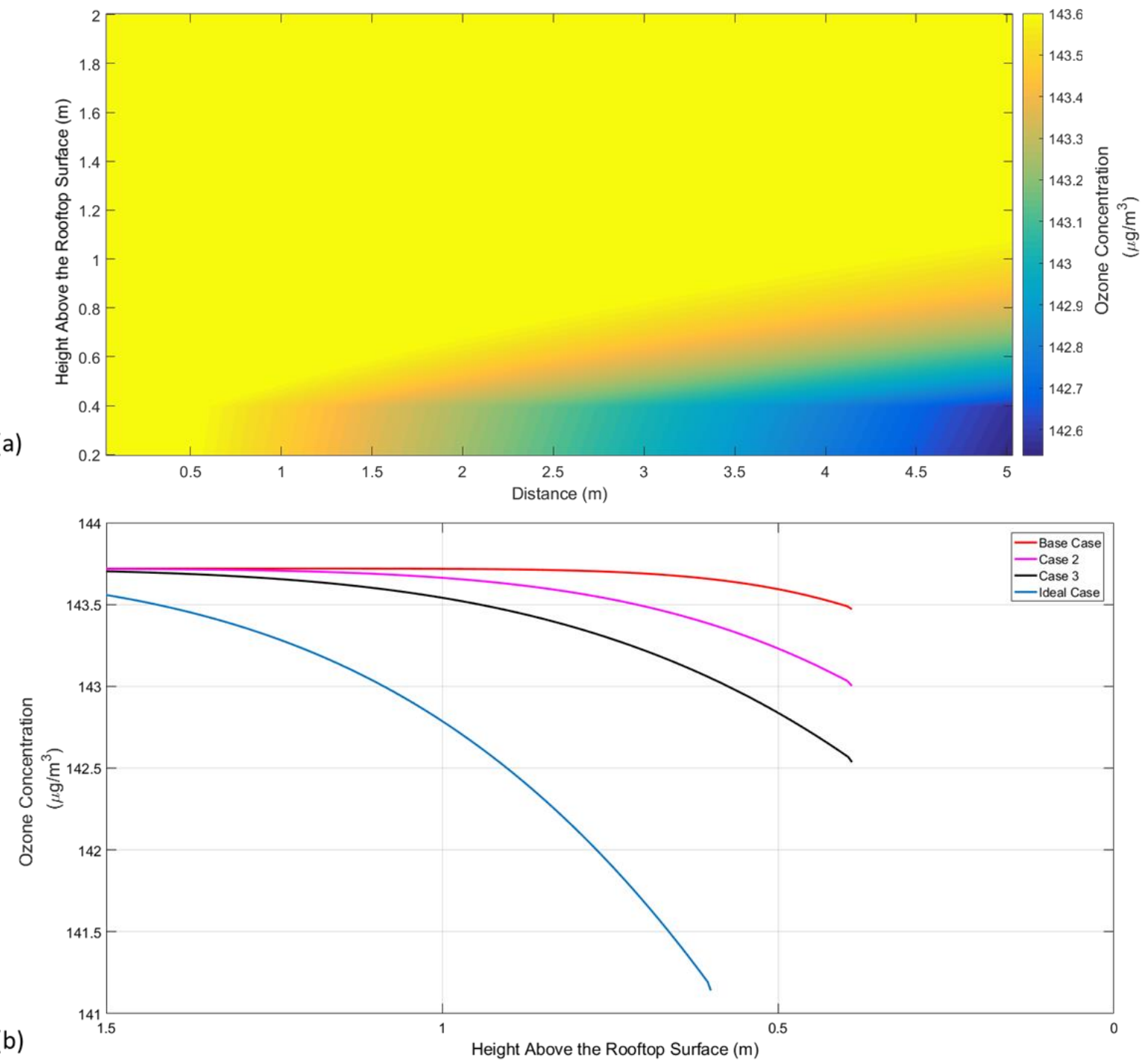

Figure 7. (a) Example of model outcome as contour plot of the 2-D advection diffusion equation for Case 3 (base case transport conditions with $5 \mathrm{~m}$ fetch length), as described in the manuscript (b) Ozone concentration profile of the column of air assumed to be entering the rooftop unit (RTU). The base case, variations in fetch length (Case $2=3 \mathrm{~m}$ and Case $3=5 \mathrm{~m}$ ), and an ideal case are represented. The ideal case was chosen to maximize deposition, where the fetch length was 5 meters, the vegetation height was $0.20 \mathrm{~m}$, the $90^{\text {th }}$ percentile friction velocity, and the $10^{\text {th }}$ percentile for heat flux and surface resistance.

The fetch length has the largest impact on $\mathrm{O}_{3}$ levels at $0.75 \mathrm{~m}$ exiting the control volume, with vegetation height, friction velocity, heat flux and surface resistance following in that order (Figure S1 in the SI). The impact of the length and vegetation height indicate geometry of the surface affects uptake more strongly than do meteorological conditions, at least for the range of conditions studied here that are indicative of extensive green roofs. Future work should further explore the impact of leaf area and intensive 
(substrate depth of approximately $15 \mathrm{~cm}$ or more) green roof designs on rooftop-scale air pollution levels. The impact of the friction velocity and heat flux are also meaningful at the rooftop scale. The Elasticity Index (EI) of friction velocity is negative, meaning greater friction velocity leads to a lower concentration at a height of 0.75 meters above the rooftop and the EI of heat flux is the opposite, lower heat flux leads to a lower concentration at that height.

The surface resistance has the smallest impact on $\mathrm{O}_{3}$ concentration at a height of $0.75 \mathrm{~m}$ above the rooftop for the variables considered. The modeled surface resistances were $46 \mathrm{~s} / \mathrm{m}, 155 \mathrm{~s} / \mathrm{m}$, and $1700 \mathrm{~s} / \mathrm{m}$ $\left(10^{\text {th }}, 50^{\text {th }}\right.$, and $90^{\text {th }}$ percentile, respectively). The $50^{\text {th }}$ percentile of friction velocity and heat flux are used to calculate the aerodynamic resistance $(236 \mathrm{~s} / \mathrm{m})$ in the roughness sublayer, held constant for the variations of surface resistance. The calculation of transport mechanisms assumes that the friction velocity and heat flux at the rooftop scale (scale of the control volume) is similar to that of urban scale field measurements. A base-case $r_{a}$ greater than the $10^{\text {th }}$ and $50^{\text {th }}$ percentiles of surface resistance explains why modelled $\mathrm{O}_{3}$ levels were least sensitive (Figure S1) to $r_{s}$ : transport resistance is large enough to limit uptake when modeled $r_{s}$ is low. The parametric approach to sensitivity analysis applied here captures the response of the rooftop system from only one approximation of the central tendency of transport and reaction; model runtimes precluded more sophisticated approaches like Monte-Carlo simulation. To address this, we modeled the "ideal" case to capture the upper-limit of removal to the rooftop if transport and surface resistances were brought to realistic, coincident minimum values (Figure 7b, blue line). Future work should explore the interdependencies of aerodynamic, boundary, and surface resistances across neighborhood and rooftop scales to better understand coupling across plant behavior and meteorology, and modeling of air pollutant dynamics.

\subsection{CONCLUSION}

This study evaluates the impact of green roof- $\mathrm{O}_{3}$ interactions near building outdoor ventilation air supply. It appears the impact of green roofs for reducing rooftop-scale $\mathrm{O}_{3}$ levels are fairly modest, with the higher range of reduction in $\mathrm{O}_{3}$ concentrations of $\sim 1.8 \mu \mathrm{g} / \mathrm{m}^{3}$ for an ideal case (modeled when ambient 
levels equal $144 \mu \mathrm{g} / \mathrm{m}^{3}$ ). Note that this result is derived from only a two-day study at a green roof in Portland, OR. The magnitude of reduction of $\mathrm{O}_{3}$ from ambient levels ranged, under ideal conditions, from $1-1.5 \%$, in close agreement with an investigation of green roof impacts on local $\mathrm{CO}_{2}$ levels [64]. Model results indicate the importance of geometry on rooftop scale levels of $\mathrm{O}_{3}$. This implies that future work could evaluate the potential of intensive green roof designs (i.e., those with larger vegetation elements) to impact air pollution levels in building outdoor ventilation air. Measurements of $\mathrm{O}_{3}$ deposition to urban greenery, generally in-line with other land surfaces, did show periods of low surface resistance. Longerterm measurements of $\mathrm{O}_{3}$ fluxes to urban greenery and green roofs are warranted to confirm these findings and to explore other drivers of surface resistance, e.g., seasonal impact on plant interaction with $\mathrm{O}_{3}$. Future studies could also measure the impact of green roofs with other pollutants and their interaction prior to entering building outdoor air supply.

\subsection{ACKNOWLEDGMENTS}

This material is based upon work supported by the National Science Foundation under Grant No. 1605843.

PR and ETG were partially supported by Portland State University Start-up funds. We would like to thank Ali Grove, Samuel Salin, David Pleshakov and Samantha Barnard for their assistance with this project.

\subsection{REFERENCES}

[1] H. Niu, C.E. Clark, J. Zhou, P. Adriaens, E.S. Division, D.U. of Technology, U. of Michigan, Scaling of economic benefits from Green Roof implementation in Washington, DC., Env. Sci Techol. 44 (2010).

[2] E. Oberndorfer, J. Lundholm, B. Bass, R.R. Coffman, H. Doshi, N. Dunnett, S. Gaffin, M. Köhler, K.K.Y. Liu, B. Rowe, Green Roofs as Urban Ecosystems: Ecological Structures, Functions, and Services, BioScience. 57 (2007) 823-833. doi:10.1641/B571005.

[3] C. Clark, P. Adriaens, F.B. Talbot, Green Roof Valuation: A Probabilistic Economic Analysis of Environmental Benefits, Environ. Sci. Technol. 42 (2008) 2155-2161. doi:10.1021/es0706652.

[4] J.D. Mullen, M. Lamsal, G. Colson, Green Roof Adoption in Atlanta, Georgia: The Effects of Building Characteristics and Subsidies on Net Private, Public, and Social Benefits, Environ. Sci. Technol. 47 (2013) 10824-10831. doi:10.1021/es401806j.

[5] D.J. Sailor, T.B. Elley, M. Gibson, Exploring the building energy impacts of green roof design decisions - a modeling study of buildings in four distinct climates, J. Build. Phys. 35 (2012) 372-391. doi:10.1177/1744259111420076. 
[6] J. Yang, Q. Yu, P. Gong, Quantifying air pollution removal by green roofs in Chicago, Atmos. Environ. 42 (2008) 7266-7273. doi:10.1016/j.atmosenv.2008.07.003.

[7] B. Stutz, Green Roofs are Starting to Sprout in American Cities, (n.d.) 6.

[8] D.J. Nowak, K.L. Civerolo, S. Trivikrama Rao, Gopal Sistla, C.J. Luley, D. E. Crane, A modeling study of the impact of urban trees on ozone, Atmos. Environ. 34 (2000) $1601-$ 1613. doi:10.1016/S1352-2310(99)00394-5.

[9] H. Taha, Modeling impacts of increased urban vegetation on ozone air quality in the South Coast Air Basin, Atmos. Environ. 30 (1996) 3423-3430. doi:10.1016/1352-2310(96)000350 .

[10] D.J. Nowak, D.E. Crane, J.C. Stevens, Air pollution removal by urban trees and shrubs in the United States, Urban For. Urban Green. 4 (2006) 115-123. doi:10.1016/j.ufug.2006.01.007.

[11] B.A. Currie, B. Bass, Estimates of air pollution mitigation with green plants and green roofs using the UFORE model, Urban Ecosyst. 11 (2008) 409-422. doi:10.1007/s11252-0080054-y.

[12] P. Sicard, E. Agathokleous, V. Araminiene, E. Carrari, Y. Hoshika, A. De Marco, E. Paoletti, Should we see urban trees as effective solutions to reduce increasing ozone levels in cities?, Environ. Pollut. 243 (2018) 163-176. doi:10.1016/j.envpol.2018.08.049.

[13] N. Carslaw, M. Ashmore, A.C. Terry, D.C. Carslaw, Crucial Role for Outdoor Chemistry in Ultrafine Particle Formation in Modern Office Buildings, Environ. Sci. Technol. 49 (2015) 11011-11018. doi:10.1021/acs.est.5b02241.

[14] K. Cho, S. Tiwari, S. Agrawal, N. Torres, M. Agrawal, A. Sarkar, J. Shibato, G. Agrawal, A. Kubo, R. Rakwal, Tropospheric Ozone and Plants: Absorption, Responses, and Consequences, Rev. Environ. Contam. Toxicol. 212 (2011) 61-111.

[15] R. Ochoa-Hueso, S. Munzi, R. Alonso, M. Arróniz-Crespo, A. Avila, V. Bermejo, R. Bobbink, C. Branquinho, L. Concostrina-Zubiri, C. Cruz, R. Cruz de Carvalho, A. De Marco, T. Dias, D. Elustondo, S. Elvira, B. Estébanez, L. Fusaro, G. Gerosa, S. IzquietaRojano, M. Lo Cascio, R. Marzuoli, P. Matos, S. Mereu, J. Merino, L. Morillas, A. Nunes, E. Paoletti, L. Paoli, P. Pinho, I.B. Rogers, A. Santos, P. Sicard, C.J. Stevens, M.R. Theobald, Ecological impacts of atmospheric pollution and interactions with climate change in terrestrial ecosystems of the Mediterranean Basin: Current research and future directions, Environ. Pollut. 227 (2017) 194-206. doi:10.1016/j.envpol.2017.04.062.

[16] A.S. Lefohn, C.S. Malley, L. Smith, B. Wells, M. Hazucha, H. Simon, V. Naik, G. Mills, M.G. Schultz, E. Paoletti, A. De Marco, X. Xu, L. Zhang, T. Wang, H.S. Neufeld, R.C. Musselman, D. Tarasick, M. Brauer, Z. Feng, H. Tang, K. Kobayashi, P. Sicard, S. Solberg, G. Gerosa, Tropospheric ozone assessment report: Global ozone metrics for climate change, human health, and crop/ecosystem research, Elem Sci Anth. 6 (2018) 28. doi:10.1525/elementa.279.

[17] M. Pascal, M. Corso, O. Chanel, C. Declercq, C. Badaloni, G. Cesaroni, S. Henschel, K. Meister, D. Haluza, P. Martin-Olmedo, S. Medina, Assessing the public health impacts of urban air pollution in 25 European cities: Results of the Aphekom project, Sci. Total Environ. 449 (2013) 390-400. doi:10.1016/j.scitotenv.2013.01.077.

[18] E. Paoletti, A. De Marco, D.C.S. Beddows, R.M. Harrison, W.J. Manning, Ozone levels in European and USA cities are increasing more than at rural sites, while peak values are decreasing, Environ. Pollut. 192 (2014) 295-299. doi:10.1016/j.envpol.2014.04.040. 
[19] P. Sicard, R. Serra, P. Rossello, Spatiotemporal trends in ground-level ozone concentrations and metrics in France over the time period 1999-2012, Environ. Res. 149 (2016) 122-144. doi:10.1016/j.envres.2016.05.014.

[20] N. Hewitt, G. Terry, Understanding ozone plant chemistry, Environ. Sci. Technol. 26 (1992) 1890-1891. doi:10.1021/es00034a004.

[21] P. Wolkoff, P.A. Clausen, C.K. Wilkins, G.D. Nielsen, Formation of Strong Airway Irritants in Terpene/Ozone Mixtures, Indoor Air. 10 (2000) 82-91. doi:10.1034/j.16000668.2000.010002082.x.

[22] C.K. Wilkins, P.A. Clausen, P. Wolkoff, S.T. Larsen, M. Hammer, K. Larsen, V. Hansen, G.D. Nielsen, Formation of Strong Airway Irritants in Mixtures of Isoprene/Ozone and Isoprene/Ozone/Nitrogen Dioxide, Environ. Health Perspect. 109 (2001) 5.

[23] R. Baraldi, L. Neri, F. Costa, O. Facini, F. Rapparini, G. Carriero, Ecophysiological and micromorphological characterization of green roof vegetation for urban mitigation, Urban For. Urban Green. (2018). doi:10.1016/j.ufug.2018.03.002.

[24] O.A. Abbass, D.J. Sailor, E.T. Gall, Ozone removal efficiency and surface analysis of green and white roof HVAC filters, Build. Environ. 136 (2018) 118-127. doi:10.1016/j.buildenv.2018.03.042.

[25] N. Kljun, P. Calanca, M.W. Rotach, H.P. Schmid, A simple two-dimensional parameterisation for Flux Footprint Prediction (FFP), Geosci. Model Dev. 8 (2015) 36953713. doi:10.5194/gmd-8-3695-2015.

[26] G.C. Edwards, Development and evaluation of a sampling system to determine gaseous Mercury fluxes using an aerodynamic micrometeorological gradient method, J. Geophys. Res. 110 (2005). doi:10.1029/2004JD005187.

[27] D.D. Baldocchi, B.B. Hicks, P. Camara, A canopy stomatal resistance model for gaseous deposition to vegetated surfaces, Atmos. Environ. 21 (1987) 91-101. doi:10.1016/00046981(87)90274-5.

[28] T.P. Meyers, D.D. Baldocchi, A comparison of models for deriving dry deposition fluxes of $\mathrm{O}_{3}$ and $\mathrm{SO}_{2}$ to a forest canopy, Tellus B. 40B (1988) 270-284. doi:10.1111/j.16000889.1988.tb00297.x.

[29] D. Baldocchi, A Multi-layer model for estimating sulfur dioxide deposition to a deciduous oak forest canopy, Atmos. Environ. 22 (1988) 869-884. doi:10.1016/0004-6981(88)902648.

[30] A.A. Karner, D.S. Eisinger, D.A. Niemeier, Near-Roadway Air Quality: Synthesizing the Findings from Real-World Data, Environ. Sci. Technol. 44 (2010) 5334-5344. doi:10.1021/es100008x.

[31] P. Keronen, A. Reissell, Ü. Rannik, T. Pohja, E. Sïvola, V. Hiltunen, P. Hari, M. Kulmala, T. Vesala, Ozone flux measurements over a Scots pine forest using eddy covariance method: performance evaluation and comparison with flux-profile method, Boreal Environ. Res. 8 (2003) 425-444.

[32] A.M. Bryan, S.B. Bertman, M.A. Carroll, S. Dusanter, G.D. Edwards, R. Forkel, S. Griffith, A.B. Guenther, R.F. Hansen, D. Helmig, B.T. Jobson, F.N. Keutsch, B.L. Lefer, S.N. Pressley, P.B. Shepson, P.S. Stevens, A.L. Steiner, In-canopy gas-phase chemistry during CABINEX 2009: sensitivity of a 1-D canopy model to vertical mixing and isoprene chemistry, Atmospheric Chem. Phys. 12 (2012) 8829-8849. doi:10.5194/acp-12-88292012. 
[33] Z.Y. Wu, L. Zhang, X.M. Wang, J.W. Munger, A modified micrometeorological gradient method for estimating $\mathrm{O}_{3}$ dry deposition over a forest canopy, Atmospheric Chem. Phys. Discuss. 15 (2015) 779-806. doi:10.5194/acpd-15-779-2015.

[34] J.H. Seinfeld, S.N. Pandis, Atmospheric chemistry and physics: from air pollution to climate change, 2nd ed, J. Wiley, Hoboken, N.J, 2006.

[35] T. Tagesson, Turbulent transport in the atmospheric surface layer, Swedish Nuclear Fuel and Waste Management Co., 2012.

[36] J. Stutz, Nitrous acid formation in the urban atmosphere: Gradient measurements of $\mathrm{NO}_{2}$ and HONO over grass in Milan, Italy, J. Geophys. Res. 107 (2002). doi:10.1029/2001JD000390.

[37] M. Aubinet, A. Grelle, A. Ibrom, Ü. Rannik, J. Moncrieff, T. Foken, A.S. Kowalski, P.H. Martin, P. Berbigier, C. Bernhofer, R. Clement, J. Elbers, A. Granier, T. Grünwald, K. Morgenstern, K. Pilegaard, C. Rebmann, W. Snijders, R. Valentini, T. Vesala, Estimates of the Annual Net Carbon and Water Exchange of Forests: The EUROFLUX Methodology, in: Adv. Ecol. Res., Elsevier, 1999: pp. 113-175. doi:10.1016/S0065-2504(08)60018-5.

[38] A. Simmons, I. Colbeck, Resistance of various building materials to ozone deposition, Environ. Technol. 11 (1990) 973-978. doi:10.1080/09593339009384949.

[39] B.B. Almand-Hunter, J.T. Walker, N.P. Masson, L. Hafford, M.P. Hannigan, Development and validation of inexpensive, automated, dynamic flux chambers, Atmospheric Meas. Tech. 8 (2015) 267-280. doi:10.5194/amt-8-267-2015.

[40] E.T. Gall, J.A. Siegel, R.L. Corsi, Modeling Ozone Removal to Indoor Materials, Including the Effects of Porosity, Pore Diameter, and Thickness, Environ. Sci. Technol. 49 (2015) 4398-4406. doi:10.1021/acs.est.5b00023.

[41] L. Pape, C. Ammann, A. Nyfeler-Brunner, C. Spirig, K. Hens, F.X. Meixner, An automated dynamic chamber system for surface exchange measurement of non-reactive and reactive trace gases of grassland ecosystems, Biogeosciences. 6 (2009) 405-429.

[42] M.W. Rotach, On the influence of the urban roughness sublayer on turbulence and dispersion, Atmos. Environ. (1999) 8.

[43] B.K. Coleman, H. Destaillats, A.T. Hodgson, W.W. Nazaroff, Ozone consumption and volatile byproduct formation from surface reactions with aircraft cabin materials and clothing fabrics, Atmos. Environ. 42 (2008) 642-654. doi:10.1016/j.atmosenv.2007.10.001.

[44] R. and A.-C.E. American Society of Heating, Standard 62.1 User's Manual: Based on ANSI/ASHRAE Standard 62.1-2016, Ventilation for Acceptable Indoor Air Quality, ASHRAE, 2016. https //books.google.com/books?id=1To7MQAACAAJ.

[45] S.K. Jain, V.P. Singh, Chapter 4 - Statistical Techniques for Data Analysis, in: S.K. Jain, V.P. Singh (Eds.), Dev. Water Sci., Elsevier, 2003: pp. 207-276. doi:10.1016/S01675648(03)80058-8.

[46] W.A. Dugas, L.J. Fritschen, L.W. Gay, A.A. Held, A.D. Matthias, D.C. Reicosky, P. Steduto, J.L. Steiner, Bowen ratio, eddy correlation, and portable chamber measurements of sensible and latent heat flux over irrigated spring wheat, Agric. For. Meteorol. 56 (1991) 120. doi:10.1016/0168-1923(91)90101-U.

[47] J.M. Craine, D.A. Wedin, F.S. Chapin, Predominance of ecophysiological controls on soil $\mathrm{CO} 2$ flux in a Minnesota grassland, (n.d.) 10.

[48] E. Velasco, S. Pressley, R. Grivicke, E. Allwine, T. Coons, W. Foster, B.T. Jobson, H. Westberg, R. Ramos, F. Hernandez, L.T. Molina, B. Lamb, Eddy covariance flux measurements of pollutant gases in urban Mexico City, Atmos Chem Phys. (2009) 18. 
[49] D.A. Hauglustaine, G.P. Brasseur, S. Walters, P.J. Rasch, J.-F. Müller, L.K. Emmons, M.A. Carroll, MOZART, a global chemical transport model for ozone and related chemical tracers: 2. Model results and evaluation, J. Geophys. Res. Atmospheres. 103 (1998) 2829128335. doi:10.1029/98JD02398.

[50] D.W. Stocker, D.H. Stedman, K.F. Zeller, W.J. Massman, D.G. Fox, Fluxes of nitrogen oxides and ozone measured by eddy correlation over a shortgrass prairie, J. Geophys. Res. 98 (1993) 12619. doi:10.1029/93JD00871.

[51] C.. Pio, M.. Feliciano, A.. Vermeulen, E.. Sousa, Seasonal variability of ozone dry deposition under southern European climate conditions, in Portugal, Atmos. Environ. 34 (2000) 195-205. doi:10.1016/S1352-2310(99)00276-9.

[52] L. Zhang, M.D. Moran, P.A. Makar, J.R. Brook, S. Gong, Modelling gaseous dry deposition in AURAMS: a unified regional air-quality modelling system, Atmos. Environ. 36 (2002) 537-560. doi:10.1016/S1352-2310(01)00447-2.

[53] D. Fowler, C. Flechard, J.N. Cape, R.L. Storeton-West, M. Coyle, Measurements of Ozone Deposition to Vegetation Quantifying the Flux, the Stomatal and Non-Stomatal Components, Water. Air. Soil Pollut. 130 (2001) 63-74. doi:10.1023/A:1012243317471.

[54] E. Velasco, S. Pressley, E. Allwine, H. Westberg, B. Lamb, Measurements of CO fluxes from the Mexico City urban landscape, Atmos. Environ. 39 (2005) 7433-7446. doi:10.1016/j.atmosenv.2005.08.038.

[55] J.B.A. Muller, M. Coyle, D. Fowler, M.W. Gallagher, E.G. Nemitz, C.J. Percival, Comparison of ozone fluxes over grassland by gradient and eddy covariance technique, Atmospheric Sci. Lett. 10 (2009) 164-169. doi:10.1002/asl.226.

[56] M.L. Wesely, Parameterization of Surface Resistances to Gaseous Dry Deposition In Regional-Scale Numerical Models, Atmos. Environ. 23 (1989) 1293-1304.

[57] I.E. Galbally, C.R. Roy, Destruction of ozone at the earth's surface, Q. J. R. Meteorol. Soc. 106 (1980) 599-620. doi:10.1002/qj.49710644915.

[58] M.W. Gallagher, K.M. Beswick, G. McFiggans, H. Coe, T.W. Choularton, Ozone Dry Deposition Velocities for Coastal Waters, in: D. Fowler, C. Pitcairn, J.-W. Erisman (Eds.), Air-Surf. Exch. Gases Part. 2000, Springer Netherlands, Dordrecht, 2001: pp. 233-242. doi:10.1007/978-94-010-9026-1_23.

[59] S.A. Cieslik, Ozone uptake by various surface types: a comparison between dose and exposure, Atmos. Environ. 38 (2004) 2409-2420. doi:10.1016/j.atmosenv.2003.10.063.

[60] G. Wieser, R. Matyssek, B. Köstner, W. Oberhuber, Quantifying ozone uptake at the canopy level of spruce, pine and larch trees at the alpine timberline: an approach based on sap flow measurement, Environ. Pollut. 126 (2003) 5-8. doi:10.1016/S02697491(03)00184-2.

[61] O. Starry, J.D. Lea-Cox, J. Kim, M.W. van Iersel, Photosynthesis and water use by two Sedum species in green roof substrate, Environ. Exp. Bot. 107 (2014) 105-112. doi:10.1016/j.envexpbot.2014.05.014.

[62] J.-L. Santiago, A. Martilli, F. Martin, On Dry Deposition Modelling of Atmospheric Pollutants on Vegetation at the Microscale: Application to the Impact of Street Vegetation on Air Quality, Bound.-Layer Meteorol. 162 (2017) 451-474. doi:10.1007/s10546-0160210-5.

[63] O. Starry, A. Aionne, P. Ramasubramanian, E.T. Gall, Shopping center ecoroof as a living laboratory in Portland, OR., in: Cities Alive, Green Roofs for Healthy Cities, Seattle, Washington, 2017. 
[64] J. Li, O.W.H. Wai, Y.S. Li, J. Zhan, Y.A. Ho, J. Li, E. Lam, Effect of green roof on ambient CO2 concentration, Build. Environ. 45 (2010) 2644-2651. doi:10.1016/j.buildenv.2010.05.025. 